\title{
Assessment of Bacterial Inoculant Delivery Methods for Cereal Crops
}

\author{
Yen Ning Chai, Stephanie Futrell and Daniel P. Schachtman* \\ Department of Agronomy and Horticulture and Center for Plant Science Innovation, University of Nebraska - Lincoln, \\ Lincoln, NE, United States
}

Despite growing evidence that plant growth-promoting bacteria can be used to improve crop vigor, a comparison of the different methods of delivery to determine which is optimal has not been published. An optimal inoculation method ensures that the inoculant colonizes the host plant so that its potential for plant growth-promotion is fully evaluated. The objective of this study was to compare the efficacy of three seed coating methods, seedling priming, and soil drench for delivering three bacterial inoculants to the sorghum rhizosphere and root endosphere. The methods were compared across multiple time

OPEN ACCESS

Edited by:

Reiner Rincón Rosales, Tuxtla Gutierrez Institute of

Technology, Mexico

Reviewed by:

Alice Checcucci,

University of Bologna, Italy

Bert Ely,

University of South Carolina,

United States

Monyck Jeane dos Santos Lopes, Museu Paraense Emílio Goeldi, Brazil

*Correspondence:

Daniel P. Schachtman daniel.schachtman@unl.edu

Specialty section:

This article was submitted to Microbe and Virus Interactions With Plants,

a section of the journal

Frontiers in Microbiology

Received: 07 October 2021

Accepted: 04 January 2022

Published: 26 January 2022

Citation:

Chai YN, Futrell $S$ and Schachtman DP (2022) Assessment of Bacterial Inoculant Delivery Methods for Cereal Crops.

Front. Microbiol. 13:791110.

doi: 10.3389/fmicb.2022.791110 points under axenic conditions and colonization efficiency was determined by quantitative polymerase chain reaction (qPCR). Two seed coating methods were also assessed in the field to test the reproducibility of the greenhouse results under non-sterile conditions. In the greenhouse seed coating methods were more successful in delivering the Grampositive inoculant (Terrabacter sp.) while better colonization from the Gram-negative bacteria (Chitinophaga pinensis and Caulobacter rhizosphaerae) was observed with seedling priming and soil drench. This suggested that Gram-positive bacteria may be more suitable for the seed coating methods possibly because of their thick peptidoglycan cell wall. We also demonstrated that prolonged seed coating for $12 \mathrm{~h}$ could effectively enhance the colonization of $C$. pinensis, an endophytic bacterium, but not the rhizosphere colonizing C. rhizosphaerae. In the field only a small amount of inoculant was detected in the rhizosphere. This comparison demonstrates the importance of using the appropriate inoculation method for testing different types of bacteria for their plant growthpromotion potential.

Keywords: inoculation, plant growth promoting bacteria, rhizosphere, endosphere, Chitinophaga, Caulobacter, Terrabacter, sorghum

\section{INTRODUCTION}

Plants and soil microbiomes have interacted and co-evolved for over a million years. Many soil-inhabiting microbes are capable of improving plant growth (Delaux and Schornack, 2021). For example, arbuscular mycorrhizal fungi and certain bacteria improve plant nutrient uptake (Parniske, 2008; Zaidi et al., 2009; Santi et al., 2013; Lopes et al., 2021b), biocontrol microbes suppress plant pathogens (Weller, 2007), while certain bacteria produce phytohormones to improve plant growth (Egamberdieva et al., 2017). To facilitate close interactions with these microbes, plants release rhizodeposits from plant roots into the rhizosphere, a soil layer adhering to the root, to serve as carbon sources and also as signaling cues to these microbes 
(Mendes et al., 2013). Apart from interacting with plants, some microbes can further colonize the inner root zone termed endosphere and those microbes are known as root endophytes. The intimate association between root endophytes and root tissues may enhance the exchange of nutrients between plants and microbes (Harman and Uphoff, 2019). For instance, the colonization of rhizobia inside root nodules allows these bacteria to fix $\mathrm{N}$ more efficiently due to the hypoxic conditions in the nodules, the fixed $\mathrm{N}$ is then supplied to the host plant in exchange for carbon (Ledermann et al., 2021).

Due to the advantages conferred by plant growth-promoting bacteria on plant vigor, using these bacteria as bioinoculants can potentially substitute or supplement chemical fertilizers that bring many adverse effects on the environment (Santos et al., 2019). The method of inoculation is an important factor that can affect the colonization of the inoculant in the host plant and impact its downstream effect on plant growth (Ciccillo et al., 2002; Müller and Berg, 2007; Fukami et al., 2016; O'Callaghan, 2016; Vassilev et al., 2020; Lopes et al., 2021b). Numerous methods have been used to deliver microbes to host plants, including soil drench, seed inoculation, and plant inoculation (Rocha et al., 2019). Seed inoculation is the most widely used on a commercial scale since it is suited to agricultural production and requires less inoculant than the other two under field conditions. To enhance the survival of the bacteria coated on the seeds, a carrier such as peat slurry or a film coat consisting of alginate polymers are often mixed with bacteria during the coating process as a layer protecting inoculants from environmental stresses such as desiccation and temperature perturbations (O'Callaghan, 2016; Lobo et al., 2019; Santos et al., 2019). Soil drench or in-furrow inoculation, on the other hand, is performed by applying the inoculants in soil before or after planting (Campo et al., 2010; Hungria et al., 2013). It has several advantages over seed inoculation as it prevents the inoculants from being inhibited by the chemicals coated on seeds (e.g., fungicides and pesticides) and can be used to deliver inoculants at higher density without being constrained by seed size (Rocha et al., 2019). However, this method is relatively impractical for field-scale compared to seed coating because higher inoculant concentration is usually required for soil inoculation to obtain desirable outcomes for plant growth (Rocha et al., 2019). Foliar spray and root dipping are two of the most commonly used methods for plant inoculation (Rocha et al., 2019). Plant inoculation is usually performed at the seedling stage because the earlier the inoculant colonizes the plant, the more likely it can persist in the plant tissues even if the plant is later colonized by other microbes (Carlstrom et al., 2019; Wippel et al., 2021). One of the greatest advantages of seedling inoculation is that it greatly enhances the plant colonization of the inoculant, but it also has the drawback of being highly impractical for use under field conditions.

Commercialization of bioinoculants began in the late 1980s and microbial inoculants have been widely applied in India and South America, especially Brazil where approximately 78\% of crops planted are inoculated annually (Santos et al., 2019). Among these commercial bioinoculants, Pseudomonas and Bacillus are the most commonly used while rhizobia are the most studied bacterial inoculants (Rocha et al., 2019). Rhizobia are not only commonly used to improve the productivity of leguminous plants as they can establish endosymbiotic relationships with legumes to fix nitrogen (Andrews and Andrews, 2017), but also have the potential to enhance non-legume growth since many of them possess other plant growth-promoting abilities such as phosphorus solubilization and phytohormone production (García-Fraile et al., 2012). Despite being widely studied, rhizobial inoculants suffer from the drawback of having a short shelf life especially when coated on seeds (O'Callaghan, 2016). Endospore-forming bacteria like Bacillus are often preferred as seed inoculants as they can better withstand unfavorable conditions (Price et al., 2010). Gram-positive bacteria which have thicker peptidoglycan layer on their cell wall are also good for bioinoculants because the cell wall renders them less susceptible to desiccation in the seed coating process compared to the Gram-negative bacteria (Viaene et al., 2016; $\mathrm{Xu}$ et al., 2018). Pseudomonas strains, despite being non-sporeforming and Gram-negative, are often used against phytopathogens such as Pythium and Fusarium due to their biocontrol properties (O'Callaghan, 2016). Although there are many bioinoculants with different plant growth-promoting potentials, the methods for delivering these bacteria under greenhouse conditions for basic research have not been compared or published.

Three bacteria isolated from field-grown sorghum were used in this study (Chai et al., 2021), with Chitinophaga pinensis (Gram-negative) originating from the root endosphere while Caulobacter rhizosphaerae (Gram-negative) and Terrabacter sp. (Gram-positive) were from the soil. Despite being widely distributed and abundant in the soil and/or rhizosphere of various crops, the genera Chitinophaga (Chung et al., 2012; Li et al., 2014; Chiniquy et al., 2021) and Caulobacter (Gao et al., 2018; Lopes et al., 2021a) are rarely tested for their plant growth-promoting abilities. Compared to these two genera, the genus Terrabacter has also been detected in many plant species, including maize (Dohrmann et al., 2013), sorghum (Lopes et al., 2021a), and napa cabbage (Bhattacharyya et al., 2018), but in very low abundance and is understudied. Therefore, we sought to determine whether these bacteria could promote plant growth and their host colonization efficiency with different inoculation methods since they are phylogenetically distinct and exhibit different cell wall structure.

In this study, we used Sorghum bicolor which is the fifth most widely grown cereal crop in the world to compare five bacterial inoculation methods. Sorghum is widely grown in marginal environments where microbial inoculation may provide strong benefits, particularly on parts of the African continent where inputs such as fertilizer are scarce (Tonitto and RickerGilbert, 2016). Our aim was to compare seedling priming, soil drench, and three seed coating methods (direct seed coating, alginate seed coating, and 12-h coating) for their efficacy of delivering three different bacterial strains to sorghum under sterile and field conditions. While it is possible to find these methods in the literature (Lopes et al., 2021b), a direct comparison under the same conditions along with a molecular analysis is not available. Our findings highlight the importance of tailoring 
the inoculation method to the specific type of bacteria being studied to get optimal plant growth-promoting results.

\section{MATERIALS AND METHODS}

\section{Bacteria Strains}

Chitinophaga pinensis isolated from sorghum root endosphere, as well as Terrabacter sp. and C. rhizosphaerae isolated from soil where sorghum was growing, were used for inoculation in this study. These bacteria have been used in a previous study (Chai et al., 2021). The draft genome sequences and gene annotations of these bacteria are available through the IMG portal at the Joint Genome Institute under the taxon ID 2818991442, 2818991454, and 2818991462, for C. pinensis, C. rhizosphaerae, and Terrabacter sp., respectively.

\section{Sorghum Seed and Potting Mix Sterilization}

A sweet sorghum variety, Grassl, was used throughout this experiment (Boyles et al., 2019). Grassl seeds were surfacesterilized for $6 \mathrm{~h}$ with chlorine gas generated by adding $3.3 \mathrm{ml}$ of hydrochloric acid to $100 \mathrm{ml}$ of sodium hypochlorite in a desiccator. Surface-sterilized seeds were then washed with sterile water and plated on YPD medium (Costanzo et al., 2001) to verify that there were no bacteria on the seed surface. The potting mix used in the greenhouse experiment consisted of two parts of peat and one part of vermiculite. To sterilize the pot and potting mix, $325 \mathrm{~g}$ of the potting mix were added to a pot with a diameter of $12.7 \mathrm{~cm}$ and autoclaved three times. After autoclaving, the potting mix was plated on YPD to ensure there were no viable microbes.

\section{Bacteria Inoculation}

All bacteria were grown in R2A broth (Reasoner and Geldreich, 1985) except for C. rhizosphaerae, which was grown in peptoneyeast extract broth (Hottes et al., 2004) because it did not grow well in R2A. Two days before planting, each bacterial strain was grown on a rotary shaker at $180 \mathrm{rpm}$ at room temperature $\left(24^{\circ} \mathrm{C}\right)$. After a day of growth, a portion of each liquid culture was transferred to a fresh medium to allow for continued growth. On the day of the experiment, each bacterial culture was pelleted at $4,000 \mathrm{rpm}$ for $10 \mathrm{~min}$ and resuspended in phosphate-buffered saline (PBS, $8 \mathrm{~g} / \mathrm{L} \mathrm{NaCl}, 0.2 \mathrm{~g} / \mathrm{L} \mathrm{KCl}$, $1.44 \mathrm{~g} / \mathrm{L} \mathrm{Na}_{2} \mathrm{HPO}_{4}$, and $0.24 \mathrm{~g} / \mathrm{L} \mathrm{KH}_{2} \mathrm{PO}_{4}$ ). The optical density (OD) of each of the bacterial/PBS suspensions was measured at $600 \mathrm{~nm}$ with a spectrophotometer and adjusted to an $\mathrm{OD}_{600}$ of 1 that corresponded to $10^{9}$ colony forming units (CFUs) for each of these bacteria before inoculation. The CFU number was derived by plating $200 \mu$ of diluted bacterial cultures with an $\mathrm{OD}_{600}$ of 1 on $\mathrm{R} 2 \mathrm{~A}$ medium.

\section{Soil Drench}

Soil drench was performed with the bacterial suspension 1 day after the plant shoot emerged from the soil. One part of each bacterial solution was added to 69 parts of $1 \times$ plant nutrient solution (Hoagland and Arnon, 1950) to achieve a final $\mathrm{OD}_{600}$ of 0.002 . Bacteria/nutrient mix equivalent to $30 \%$ of the soil volume was then added to each pot in a laminar flow hood.

\section{Direct Seed Coating}

Surfaced-sterilized seeds were dipped into the bacteria suspension in PBS and air-dried for $20 \mathrm{~min}$ in the laminar flow hood before planting.

\section{Twelve Hours Seed Coating}

Surface-sterilized seeds were immersed in bacteria suspension in PBS and put on a rotary shaker shaking at $180 \mathrm{rpm}$ for $12 \mathrm{~h}$ at room temperature and air-dried for $20 \mathrm{~min}$ in the laminar flow hood before planting.

\section{Alginate Seed Coating}

Surface-sterilized seeds were dipped into bacteria suspension in $2 \%(\mathrm{wt} / \mathrm{vol})$ alginate followed by transferring the seeds into $0.1 \mathrm{M} \mathrm{CaCl}_{2}$ to solidify. The alginate-coated seeds were then air-dried in the laminar flow hood for $20 \mathrm{~min}$ before planting.

\section{Seedling Priming}

Surface-sterilized seeds were germinated at $30^{\circ} \mathrm{C}$ in a sterilized petri dish with wet filter paper for 24 hours. When seeds germinated they were carefully transferred to a new petri dish filled with bacteria suspension in PBS and placed on a rotary shaker at $20 \mathrm{rpm}$ for $12 \mathrm{~h}$. The inoculated seedlings were then sowed carefully in soil in a laminar flow hood.

\section{No Microbe Control}

In a laminar flow hood, 1:69 of PBS in 1X Hoagland solution was added to each pot right after germination.

To measure the concentration of viable bacteria on inoculated sorghum seeds, 10 inoculated seeds were placed in $10 \mathrm{ml}$ of PBS and vortex vigorously for $10 \mathrm{~min}$ followed by a 4 -fold serial dilution in PBS. About $200 \mu \mathrm{l}$ of each dilution was then plated on R2A medium and allowed to grow at room temperature. Approximately $10^{3}-10^{4} \mathrm{CFU}$ per seed were detected for the three bacteria with seed inoculation.

\section{Experimental Design Greenhouse Experiment}

This experiment was comprised of a total of 240 pots (three bacterial strains $\times$ five inoculation methods $\times$ five replicate pots $\times$ three sampling time points + five uninoculated control $\times$ three sampling time points). Pots were planted on March 1, 2019. In a sterile laminar flow hood, three seeds were planted into the sterile soil in each pot and the pots were covered with saucers before transferring to the greenhouse to minimize airborne contamination. Pots were arranged in the greenhouse in a completely randomized design. Seedlings were thinned to one plant per pot and a small hole was made on each saucer covering the pot to allow for shoot growth. The greenhouse was $27^{\circ} \mathrm{C}$ during the day and $21^{\circ} \mathrm{C}$ at night, with a photoperiod of $16 \mathrm{~h}$. Sterilized water and 1X Hoagland nutrient solution were applied 
to each pot to keep the soil evenly wet through a sterile plastic tube into the hole on the saucers covering the pot. Three samplings were conducted at 4-, 6-, and 8-week after planting. For each harvest, fresh and dry weights of both shoot and root were measured. Roots were washed to remove the soil prior to weighing. To obtain the dry weight, fresh plant material was dried in an oven at $60^{\circ} \mathrm{C}$ for 3 days. Rhizosphere and root tissues were collected for qPCR analysis to quantify the colonization of inoculated microbes.

\section{Field}

Grassl seeds were inoculated with each of the three bacteria using alginate and $12 \mathrm{~h}$ coating and were planted in a field $(40.85475,-96.61)$ on June 1,2019 . The field soil was a silty loam with $3.9 \%$ organic matter, and the concentrations of some major chemical components of the soil were: $\mathrm{pH}$ : 5.55 ; $28 \mathrm{ppm}$ nitrate-N; $446 \mathrm{ppm}$ potassium; $10.7 \mathrm{ppm}$ sulfate; $1,657 \mathrm{ppm}$ calcium; and 253 ppm magnesium. Seed inoculation was carried out on the day before planting and planted immediately the next morning. A total of 64 plots $(3.7 \mathrm{~m} \times 1.5 \mathrm{~m})$ were included in this experiment (three bacteria and no-microbe control $\times$ two inoculation methods $\times$ eight replicates) and arranged in complete randomized design. Early in the field study, $78.5 \mathrm{~kg} / \mathrm{ha}$ of nitrogen fertilizer was applied in the form of urea. Weeding was carried out frequently and a weed score was assigned for each plot early on during the experiment with a range from 0 to 3 , with the score of zero indicating no weeds and three designating severe weed infestation. The rhizosphere and root samples were collected twice, once at the vegetative (July 10, 2019) stage and a second time at flowering (August 23, 2019) for qPCR analysis to quantify the number of bacteria colonizing the rhizosphere and root. Shoot fresh weight and dry weight were measured twice during the course of the experiment. Biomass was measured on July 10 (30 days after germination) and October 8, 2019 (120 days after germination). Additionally, grain yield was also measured in October.

\section{Sampling and Processing of Rhizosphere and Root Tissue for qPCR \\ Sampling}

To collect root and rhizosphere, we removed the bulk soil from the root system, chose a range of root types, and put them in a $50 \mathrm{ml}$ tube filled with $35 \mathrm{ml}$ of phosphate buffer $\left(6.33 \mathrm{~g} / \mathrm{L} \quad \mathrm{NaH}_{2} \mathrm{PO}_{4} \quad\right.$ and $\quad 8.5 \mathrm{~g} / \mathrm{L} \quad \mathrm{Na}_{2} \mathrm{HPO}_{4}$ anhydrous) supplemented with $0.01 \%$ of Silwet and shook them vigorously for $3 \mathrm{~min}$ on a vortexer. The roots were then transferred to a clean $50 \mathrm{ml}$ tube, the remaining phosphate buffer with rhizosphere soil was collected (McPherson et al., 2017).

\section{Rhizosphere Processing}

The rhizosphere soil samples were filtered through a sterile $100 \mu \mathrm{m}$ mesh filter unit (Fisher Scientific, United States) into a clean $50 \mathrm{ml}$ tube and pelleted at $6,000 \times g$ for $5 \mathrm{~min}$ at room temperature using a centrifuge. The pellet was resuspended in $1.5 \mathrm{ml}$ phosphate buffer and transferred to a sterile $2 \mathrm{ml}$ tube. The rhizosphere was re-pelleted by spinning tubes for $2 \mathrm{~min}$ at full speed. The supernatant was drained from the tube and stored at $-20^{\circ} \mathrm{C}$ until DNA extraction.

\section{Root Processing}

Roots were surface sterilized by rinsing for $1 \mathrm{~min}$ in $50 \%$ sodium hypochlorite $+0.005 \%$ Tween 20 , followed by a $1 \mathrm{~min}$ rinse in $70 \%$ ethanol, and three rinses in sterile ultrapure water for $1 \mathrm{~min}$ each. Roots were blotted dry, placed in a $2 \mathrm{ml}$ microfuge tube, and frozen at $-80^{\circ} \mathrm{C}$ prior to being ground in liquid $\mathrm{N}$ for DNA extraction.

\section{DNA Extraction of the Rhizosphere, and Root Samples}

Rhizosphere DNA was extracted using MagAttract $^{\circledR}$ PowerSoil ${ }^{\circledR}$ DNA KF Kit (Qiagen) and root DNA using MagMAX $^{\mathrm{TM}}$ Plant DNA Kit (ThermoFisher Scientific), with a KingFisher Flex Robot (ThermoFisher Scientific) following the manufacturer's protocol. DNA concentration was quantified using QuantiFluor ${ }^{\circledR}$ dsDNA System (Promega) with CLARIOstar ${ }^{\circledR}$ Plus microplate reader (BMG LABTECH) following the manufacturer's protocol.

\section{qPCR}

Different primer pairs were used for each bacterium to provide adequate specificity for each of the three bacteria used in this study. These primer pairs were constructed from the corresponding genome sequence of each isolate (Table 1). Standard curves were constructed by serial dilutions of the genomic DNA of each bacterium from $10^{6}$ to $10^{1} \mathrm{pg}$ DNA $\mu \mathrm{l}^{-1}$ using molecular grade water. The genome copy number of each bacteria was computed using their genome sizes, (C. rhizosphaerae: 5563326 bp, Terrabactor sp.: 4320267 bp, and C. pinensis: $8318214 \mathrm{bp})$, DNA molecular weight of $650 \mathrm{Dabp}^{-1}$, and Avogadro's constant of $6.022 \times 10^{23}$. The detection limit of C. rhizosphaerae, C. pinensis, and Terrabacter sp. were 13, 7, and 7 genome copies, respectively. All qPCR was carried out using CFX Connect (Bio-Rad Laboratories Inc., Hercules, CA, United States) in a final volume of $10 \mathrm{ml}$, which contained $5 \mathrm{ml}$ of Power Sybr Green PCR Master Mix (Applied Biosystems, Foster City, CA, United States), $0.5 \mathrm{ml}$ of each of the forward and reverse primers (10 pM each), $1 \mathrm{ng}$ of template DNA, and water. The same amplification

TABLE 1 | Primer pairs used to amplify the three bacterial isolates.
Primer sequence (5'-3')

\section{Chitinophaga pinensis}

1204_1F 1204_1R 3260_2F 3260_2F
3260 2R Terrabacter sp. 3264 2F 3260_2R
TTCCGTGCCTCATACTCAGA CCTCAGGAGCAAGTCCATTC sphaerae GCTTCAACTTAGGCCTGTCG GGGCGGTCTACTAAACATCG

ATTCAAGTGCATGGTGAACG GTCAAAGCCACAGTCGATGA
Amplicon size

(bp)

150
165 
conditions were used for all three bacteria with an initial incubation at $95^{\circ} \mathrm{C}$ for $10 \mathrm{~min}$, followed by 40 cycles of denaturation at $95^{\circ} \mathrm{C}$ for $15 \mathrm{~s}$, annealing at $60^{\circ} \mathrm{C}$ for $30 \mathrm{~s}$, and extension at $72^{\circ} \mathrm{C}$ for $15 \mathrm{~s}$. The specificity of amplification was determined using a melting curve analysis at the end of the amplification by ramping the temperature up to $95^{\circ} \mathrm{C}$ for $1 \mathrm{~min}$ followed by a $0.5^{\circ} \mathrm{C} \mathrm{s}^{-1}$ increment from 60 to $95^{\circ} \mathrm{C}$. Three technical replicates were performed for each sample in the qPCR. The average of the three $\mathrm{Ct}$ values from the technical replicates was calculated and reported.

\section{Statistical Analysis}

All the statistical analyses in this study were performed using R v3.6.0 (R Developmental Core Team, 2018). A one-way ANOVA was performed to determine whether the colonization of the inoculated bacteria (logarithm of bacterial copy number) in the rhizosphere and root endosphere was influenced by inoculation method. Tukey's HSD post hoc pairwise comparison was then conducted to compare the mean difference between inoculation methods. These analyses were performed on both the greenhouse and field datasets.

Linear models were constructed using $\operatorname{lm}$ function to determine the changes in sorghum shoot and root dry biomass for each combination of inoculation method, bacterial strain, sampling time point, and degree of colonization (log copy number). Prior to model construction, root and shoot dry weight were power-transformed by 0.222 and 0.303 , respectively, which were determined using boxcox function in "MASS" package (Venables and Ripley, 2002) to homogenize the residual variances. Backward selection was performed to eliminate the interactions that were not significant in affecting sorghum biomass from the global models. The marginal means for each treatment and strain combination were computed and subjected to Tukey's HSD pairwise comparisons using the emmeans function in "emmeans" package (Lenth, 2021). Plots were generated using ggboxplot and ggplot function in "ggpubr" (Kassambara, 2020) and "ggplot2" package (Wickham, 2016), respectively.

\section{RESULTS}

\section{Primer Specificity}

To construct primer pairs specific for each bacterial isolate, we first mapped each genome sequence to the NCBI database to identify the genomic regions that were unique to each of the three bacterial isolates and not found in their close relatives. As a result, we identified the genomic regions that exhibited zero matches when searched using the BLAST alignment tool. Using these unique genomic regions, we constructed three primer pairs for these isolates (Table 1). We further confirmed the specificity of these primers on the targeted strains by performing specificity tests on their closely related isolates in our culture collection from sorghum in the same field, some of which have a perfect match $(100 \%$ similarity) with our targeted bacteria in their full-length 16S rRNA regions (Table 2; Supplementary Table 1).

\section{Quantification of Bacterial Colonization in Rhizosphere and Root Endosphere Under Sterile Greenhouse Conditions}

All three bacteria were detectable in the rhizosphere of the inoculated plants up to 8 weeks after planting (Figure 1). The colonization of $C$. rhizosphaerae in the rhizosphere was greater $\left(10^{4}-10^{5}\right.$ copies per ng of rhizosphere DNA) when the seedling priming and soil drench method were used as compared to the seed coating approaches $\left(10^{2}-10^{3}\right.$ copies per ng of rhizosphere DNA; Figure 1A). Similar trend was also found for $C$. pinensis where seedling priming and soil drench method promoted its colonization in the rhizosphere (Figure 1B). Prolonged seed coating for $12 \mathrm{~h}$ enhanced the colonization of $C$. pinensis (Figure 1B) but did not improve the colonization of $C$. rhizosphaerae in the rhizosphere (Figure 1A). The colonization of Terrabacter sp. in sorghum rhizosphere was consistent in all five inoculation methods; although its abundance was lower $\left(10^{2}\right.$ copies per ng of rhizosphere DNA) as compared to the other two strains which reached as high as $10^{5}$ copies per ng of rhizosphere DNA (Figure 1C). C. pinensis and C. rhizosphaerae but not Terrabacter sp. were detected in the rhizosphere of the uninoculated control at week 8 after planting (Figures 1A,B).

C. pinensis was the only strain that could robustly colonize the root endosphere starting from week 6 after planting (Figures $2 \mathbf{A}-\mathbf{C}$ ). The colonization of $C$. pinensis in the root endosphere was greater when inoculated with seedling priming

TABLE 2 | Bacterial strains used to test the specificity of each primer pair.

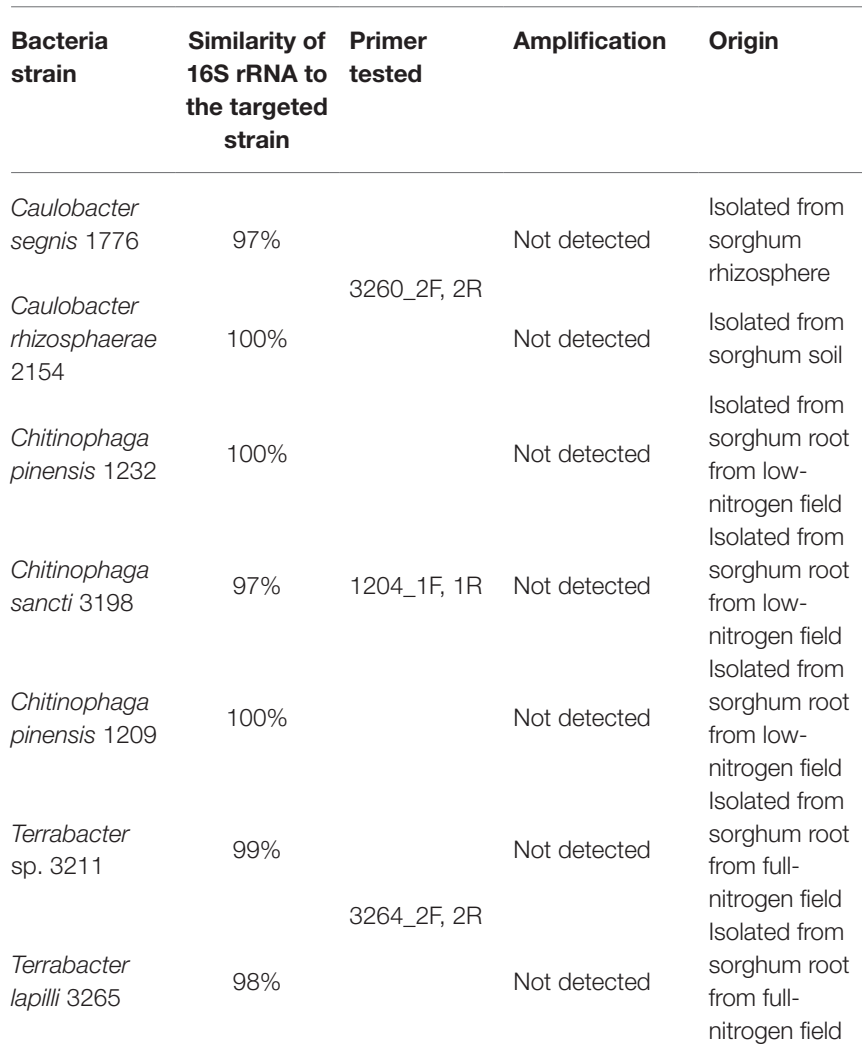




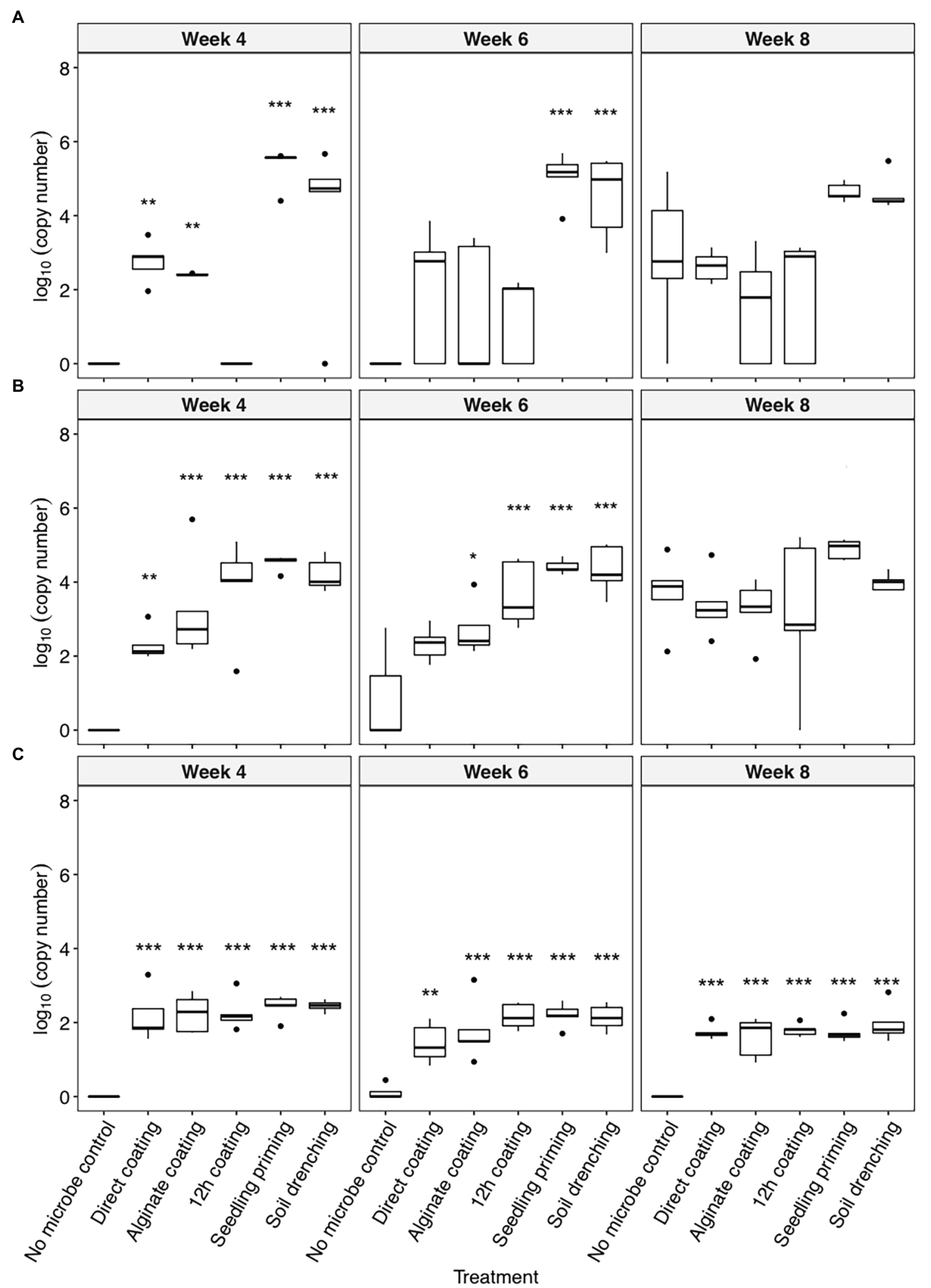

FIGURE 1 | The colonization [ $\log _{10}$ (bacterial DNA copy number)/ng of rhizosphere DNA] of (A) Caulobacter rhizosphaerae, (B) Chitinophaga pinensis, and (C) Terrabacter sp. in the rhizosphere of Sorghum bicolor inoculated using different methods at week 4, 6, and 8 after planting. ANOVA was performed with Tukey's HSD correction for multiple comparisons. Asterisks denote significant difference in the bacteria DNA copy number between inoculated samples and uninoculated controls. ${ }^{*} p \leq 0.05,{ }^{* *} p \leq 0.01,{ }^{\star * *} p \leq 0.001$. 


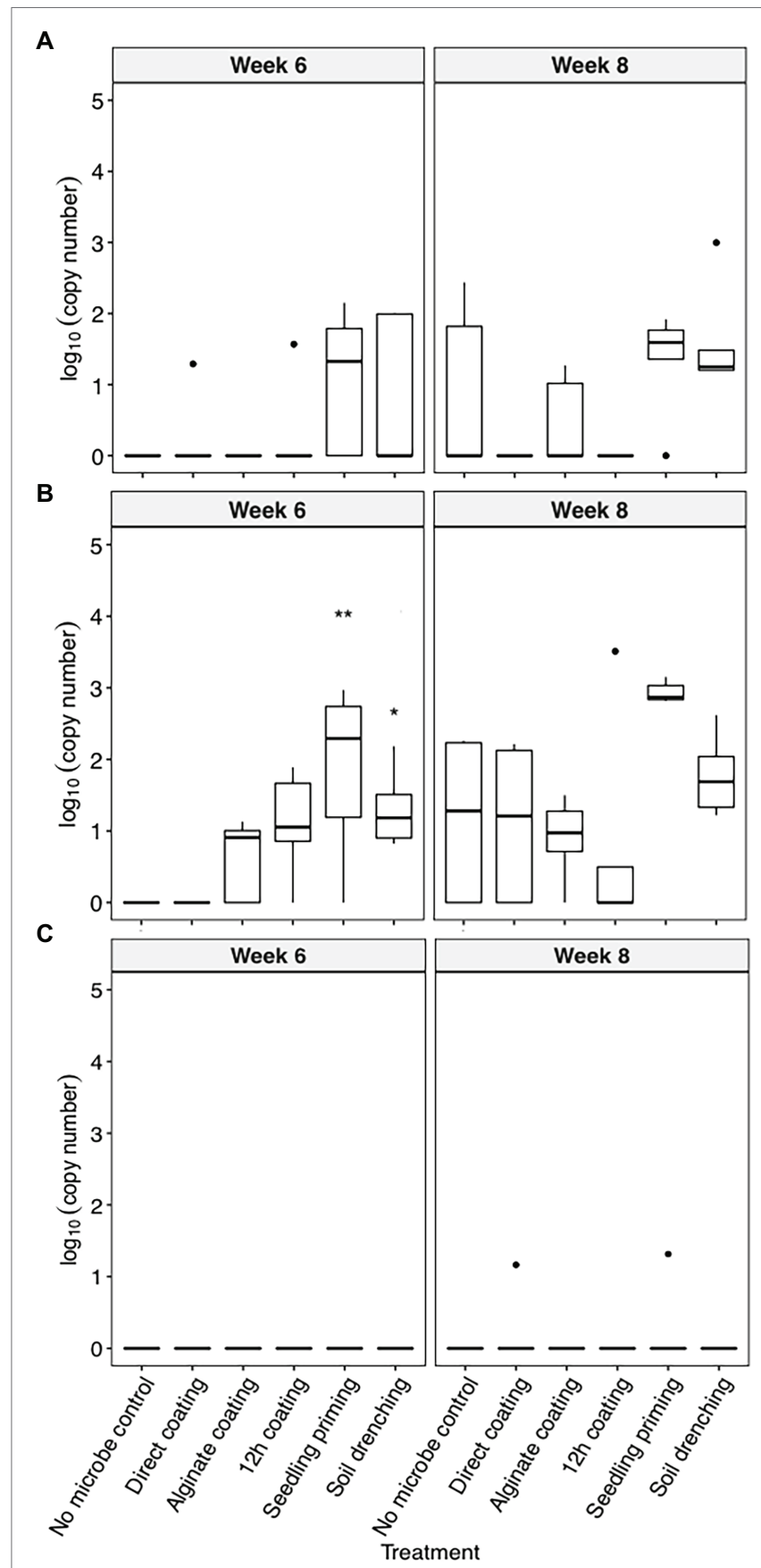

FIGURE 2 | The colonization [ $\log _{10}$ (bacterial DNA copy number)/ng of root endosphere DNA] of (A) C. rhizosphaerae, (B) C. pinensis, and

(C) Terrabacter $\mathrm{sp}$. in the root endosphere of $\mathrm{S}$. bicolor inoculated using different methods at week 4, 6, and 8 after planting. ANOVA was performed with Tukey's HSD correction for multiple comparisons. Asterisks denote significant difference in the bacteria DNA copy number between inoculated samples and uninoculated controls. ${ }^{*} p \leq 0.05,{ }^{* *} p \leq 0.01$.

\section{The Effect of Bacterial Isolate Inoculation on Plant Growth Under Sterile Greenhouse Condition}

Linear models were used to determine the changes in sorghum root and shoot dry biomass for each combination of bacterial strain, inoculation method, sampling timepoint, and degree of colonization (log copy number). Overall, all three bacteria exhibited a certain amount of root growth promotion (Figures $3 \mathrm{~A}-\mathbf{C}$ ), with Terrabacter sp. being particularly stronger than the other two at enhancing root growth on week 6 after planting (Figure 3B; Table 3). The degree of growth-promotion from these bacteria was affected by the inoculation methods. Although significant root growth-promotion was measured when inoculating Terrabacter sp. with all five inoculation methods, the degree of growth enhancement was greater when the three seed coating methods were used (Figure 3; Table 3). On the other hand, greater root growth-promotion was detected when inoculating C. rhizosphaerae and $C$. pinensis with the seedling priming compared to other inoculation methods (Figure 3). In fact, root growth-promotion from C. rhizosphaerae was only detectable with seedling priming despite this effect being marginally significant. For C. pinensis, significant root growth-promotion was also observed with alginate coating and marginally significant for $12 \mathrm{~h}$ coating. No significant root growth-promotion was measured when inoculating C. rhizosphaerae and C. pinensis with soil drench method.

Among the three bacteria used, only $C$. pinensis and Terrabacter sp. exhibited significant shoot growth enhancement (Figures 4A-C; Table 4). Significant shoot growth-promotion from C. pinensis was measured when inoculated with seedling priming, alginate, and $12 \mathrm{~h}$ coating methods. Significant shoot growth-promotion was also observed when Terrabacter sp. was inoculated with the same seed coating methods but not the seedling priming.

\section{Quantification of Bacterial Colonization in Rhizosphere Under Field Condition}

Alginate and $12 \mathrm{~h}$ coating method were further tested in the field to assess their efficacy for delivering the three bacterial inoculants to sorghum rhizosphere under non-sterile conditions in which there would be competition from the native microbial communities. While C. rhizosphaerae and C. pinensis were detected in the rhizosphere up to 12 weeks after inoculation in the field, DNA copy numbers in the rhizosphere of the inoculated plants were lower as compared to that of the greenhouse experiment and not significantly different from the uninoculated control (Figures 5A,B). Terrabacter sp. was not detected in either of the sampling timepoints (Figure 5C). No significant improvement in shoot dry weight was measured for all bacteria and inoculation treatment combinations at both sampling timepoints (Figures 6A,B). Bacterial colonization in the root endosphere was not quantified due to the lack of biomass difference between the inoculated plants and the uninoculated controls.

\section{DISCUSSION}

The application of plant growth-promoting bacteria has been adopted in many countries, especially Brazil to improve crop 


\section{A}

- Caulobacter - Chitinophaga - Terrabacter

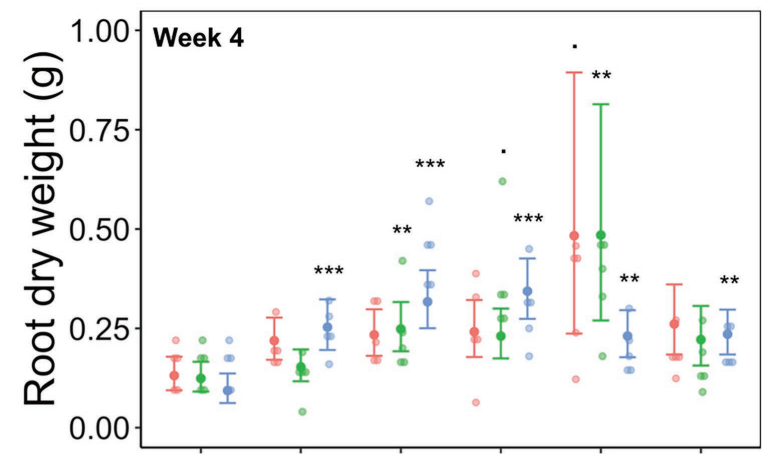

B

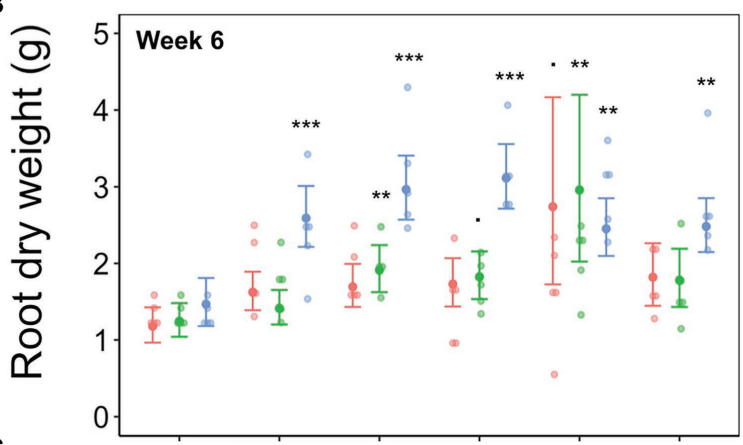

C

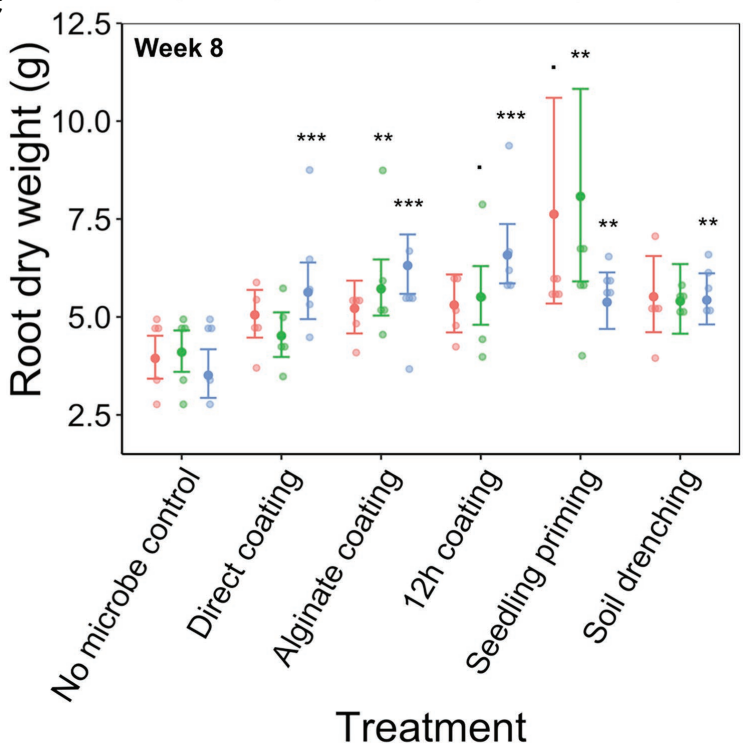

FIGURE 3 | Effects of bacterial inoculation using different inoculation methods on S. bicolor root dry weight at week (A) 4, (B) 6, and (C) 8 after planting. Root dry weight was fitted to linear model and Tukey's HSD correction was performed for multiple comparisons. Error bars and center points denote the $95 \% \mathrm{Cls}$ and the marginal means for each strain and inoculation method combination, respectively, derived from the linear model. The distribution of raw data is represented by the dots. ${ }^{*} p \leq 0.1,{ }^{* *} p \leq 0.01$, ${ }^{\star \star \star} p \leq 0.001$.

yields and reduce the input of chemical fertilizer (Santos et al., 2019). However, there is a lack of publicly available literature that compares inoculation methods to determine which approach is more effective at delivering bacterial inoculants to the targeted
TABLE 3 | Linear model testing the effect of the degree of colonization (log copy number), bacterial strain, inoculation method, and their interactions on sorghum root dry weight.

\begin{tabular}{|c|c|c|c|c|}
\hline & Estimate & Std. error & $t$ value & $p$ value \\
\hline (Intercept) & 0.663 & 0.020 & 32.826 & $<0.001$ \\
\hline Log copy number & -0.010 & 0.007 & -1.425 & 0.155 \\
\hline Chitinophaga & -0.008 & 0.028 & -0.282 & 0.778 \\
\hline Terrabacter & -0.046 & 0.028 & -1.655 & 0.099 \\
\hline Direct coating & 0.038 & 0.038 & 0.991 & 0.323 \\
\hline Alginate coating & 0.071 & 0.030 & 2.378 & 0.018 \\
\hline $12 \mathrm{~h}$ coating & 0.028 & 0.026 & 1.089 & 0.277 \\
\hline Seedling priming & 0.298 & 0.120 & 2.478 & 0.014 \\
\hline Soil drench & 0.117 & 0.055 & 2.132 & 0.034 \\
\hline Time Week 6 & 0.400 & 0.017 & 23.553 & $<0.001$ \\
\hline Time Week 8 & 0.719 & 0.018 & 41.001 & $<0.001$ \\
\hline $\begin{array}{l}\text { Log copy number*Direct } \\
\text { coating }\end{array}$ & 0.016 & 0.014 & 1.133 & 0.258 \\
\hline $\begin{array}{l}\text { Log copy } \\
\text { number*Alginate coating }\end{array}$ & 0.006 & 0.012 & 0.537 & 0.592 \\
\hline $\begin{array}{l}\text { Log copy number } 12 \mathrm{~h} \\
\text { coating }\end{array}$ & 0.025 & 0.011 & 2.261 & 0.025 \\
\hline $\begin{array}{l}\text { Log copy } \\
\text { number*Seedling priming }\end{array}$ & -0.034 & 0.025 & -1.367 & 0.173 \\
\hline $\begin{array}{l}\text { Log copy number"Soil } \\
\text { drench }\end{array}$ & -0.005 & 0.013 & -0.37 & 0.712 \\
\hline $\begin{array}{l}\text { Chitinophaga*Direct } \\
\text { coating }\end{array}$ & -0.047 & 0.034 & -1.397 & 0.164 \\
\hline $\begin{array}{l}\text { Terrabacter"Direct } \\
\text { coating }\end{array}$ & 0.069 & 0.035 & 1.994 & 0.047 \\
\hline $\begin{array}{l}\text { Chitinophaga*Alginate } \\
\text { coating }\end{array}$ & 0.018 & 0.036 & 0.484 & 0.629 \\
\hline $\begin{array}{l}\text { Terrabacter*Alginate } \\
\text { coating }\end{array}$ & 0.097 & 0.034 & 2.848 & 0.005 \\
\hline $\begin{array}{l}\text { Chitinophaga*12h } \\
\text { coating }\end{array}$ & 0.000 & 0.041 & 0.009 & 0.993 \\
\hline Terrabacter" $12 \mathrm{~h}$ coating & 0.105 & 0.035 & 2.995 & 0.003 \\
\hline $\begin{array}{l}\text { Chitinophaga*Seedling } \\
\text { priming }\end{array}$ & 0.008 & 0.035 & 0.242 & 0.809 \\
\hline $\begin{array}{l}\text { Terrabacter"Seedling } \\
\text { priming }\end{array}$ & -0.083 & 0.076 & -1.09 & 0.277 \\
\hline Chitinophaga*Soil drench & -0.019 & 0.034 & -0.554 & 0.580 \\
\hline Terrabacter"Soil drench & 0.029 & 0.042 & 0.698 & 0.486 \\
\hline Chitinophaga"Week 6 & 0.021 & 0.024 & 0.872 & 0.384 \\
\hline Terrabacter"Week 6 & 0.098 & 0.024 & 4.143 & $<0.001$ \\
\hline Chitinophaga"Week 8 & 0.020 & 0.025 & 0.802 & 0.424 \\
\hline Terrabacter"Week 8 & 0.012 & 0.024 & 0.483 & 0.630 \\
\hline
\end{tabular}

Backward selection was performed and the non-significant interactions (log copy number*strain, log copy number*sampling time, and treatment"sampling time) were removed from the model.

plant to test their plant growth-promoting potential. To our knowledge, this is the first comprehensive study that evaluated the efficacy of multiple inoculation methods for delivering phylogenetically distinct inoculants to a cereal crop under sterile and non-sterile field conditions. We tested five inoculation methods and demonstrated that all the methods tested were successful at delivering at least one bacterial inoculant to sorghum under sterile conditions. However, the degree of plant growth-promotion from the inoculants was impacted by inoculation method. Two inoculation methods suitable for field planting, alginate and $12 \mathrm{~h}$ coating were tested under field condition but only a negligible amount of inoculated bacteria were detected in the rhizosphere. This may have been because the bacterial isolate concentration 


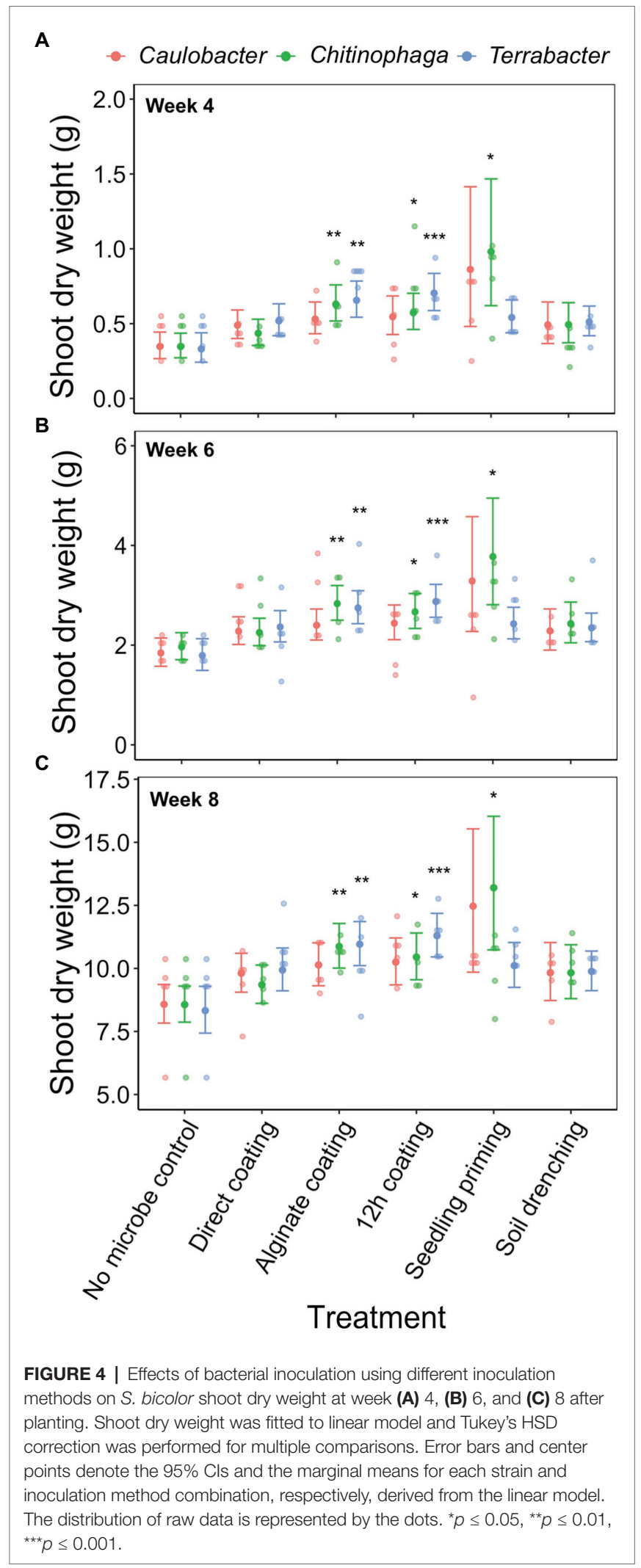

used to coat the seeds $\left(10^{3}-10^{4} \mathrm{CFU}\right.$ per seed) was too low to facilitate their establishment in sorghum rhizosphere under
TABLE 4 | Linear model testing the effect of the degree of colonization (log copy number), bacterial strain, inoculation method, and their interactions on sorghum shoot dry weight.

\begin{tabular}{|c|c|c|c|c|}
\hline & Estimate & Std. error & $t$ value & $p$ value \\
\hline (Intercept) & 0.760 & 0.025 & 30.299 & $<2 \mathrm{e}-16$ \\
\hline Log copy number & -0.014 & 0.009 & -1.541 & 0.125 \\
\hline Chitinophaga & 0.000 & 0.034 & 0.002 & 0.998 \\
\hline Terrabacter & -0.011 & 0.035 & -0.308 & 0.758 \\
\hline Direct coating & 0.025 & 0.047 & 0.527 & 0.599 \\
\hline Alginate coating & 0.107 & 0.037 & 2.885 & 0.004 \\
\hline $12 \mathrm{~h}$ coating & 0.042 & 0.032 & 1.295 & 0.197 \\
\hline Seedling priming & 0.331 & 0.150 & 2.214 & 0.028 \\
\hline Soil drench & 0.073 & 0.068 & 1.063 & 0.289 \\
\hline Week 6 & 0.478 & 0.021 & 22.660 & $<2 \mathrm{e}-16$ \\
\hline Week 8 & 1.192 & 0.022 & 54.715 & $<2 \mathrm{e}-16$ \\
\hline $\begin{array}{l}\text { Log copy number* Direct } \\
\text { coating }\end{array}$ & 0.022 & & 1.282 & 0.201 \\
\hline $\begin{array}{l}\text { Coating } \\
\text { Log copy }\end{array}$ & 0.022 & 0.017 & 1.282 & 0.201 \\
\hline $\begin{array}{l}\text { number"Alginate coating } \\
\text { Log copy number" } 12 \mathrm{~h}\end{array}$ & -0.003 & 0.015 & -0.181 & 0.857 \\
\hline coating & 0.026 & 0.014 & 1.842 & 0.067 \\
\hline $\begin{array}{l}\text { Log copy } \\
\text { number*Seedling }\end{array}$ & & & & \\
\hline $\begin{array}{l}\text { priming } \\
\text { Log copy number*Soil }\end{array}$ & -0.040 & 0.031 & -1.310 & 0.192 \\
\hline $\begin{array}{l}\text { drench } \\
\text { Chitinophaga*Direct }\end{array}$ & 0.003 & 0.017 & 0.203 & 0.840 \\
\hline coating & -0.028 & 0.042 & -0.671 & 0.503 \\
\hline $\begin{array}{l}\text { Terrabacter"Direct } \\
\text { coating }\end{array}$ & 0.025 & 0.043 & 0.575 & 0.566 \\
\hline $\begin{array}{l}\text { Chitinophaga"Alginate } \\
\text { coating }\end{array}$ & 0.044 & 0.045 & 0.974 & 0.331 \\
\hline $\begin{array}{l}\text { Terrabacter*Alginate } \\
\text { coating }\end{array}$ & 0.065 & 0.042 & 1.546 & 0.123 \\
\hline Chitinophaga*12h & & & & 0.805 \\
\hline coating & 0.012 & 0.050 & 0.248 & 0.805 \\
\hline $\begin{array}{l}\text { Terrabacter } 12 \text { h coating } \\
\text { Chitinophaga*Seedling }\end{array}$ & 0.077 & 0.044 & 1.773 & 0.077 \\
\hline $\begin{array}{l}\text { Chitinophaga*Seedling } \\
\text { priming } \\
\text { Terrabacter Seedling }\end{array}$ & 0.038 & 0.043 & 0.882 & 0.379 \\
\hline $\begin{array}{l}\text { priming } \\
\text { Chitinophaga*Soil }\end{array}$ & -0.115 & 0.094 & -1.221 & 0.223 \\
\hline drench & 0.001 & 0.042 & 0.014 & 0.989 \\
\hline Terrabacter"Soil drench & 0.020 & 0.052 & 0.388 & 0.699 \\
\hline Chitinophaga"Week 6 & 0.023 & 0.030 & 0.790 & 0.431 \\
\hline Terrabacter Week 6 & 0.000 & 0.029 & 0.003 & 0.998 \\
\hline Chitinophaga"Week 8 & -0.001 & 0.030 & -0.024 & 0.981 \\
\hline Terrabacter"Week 8 & -0.006 & 0.030 & -0.210 & 0.834 \\
\hline
\end{tabular}

Backward selection was performed and the non-significant interactions (log copy number"strain, log copy number"sampling time, and treatment"sampling time) were removed from the model.

non-sterile conditions where there is competition from the natural microbial communities (Mendoza-Suárez et al., 2021). Although a standard of $10^{4}$ rhizobial cells per seed is widely used to inoculate legumes with medium-size seed (e.g., mung bean and pigeon pea) like sorghum (Lupwayi et al., 2000), this may not be applicable for the inoculation of non-rhizobia species and for non-legumes. On the other hand, successful colonization from inoculated bacteria was demonstrated in sorghum from a starting bacterial concentration as low as $10^{2} \mathrm{CFU}$ per seed under sterile conditions (Luna et al., 2010). Despite the fact that the inoculation methods used in the field study failed to facilitate higher than 


\section{A}

\section{官 No microbe control 追 Caulobacter}

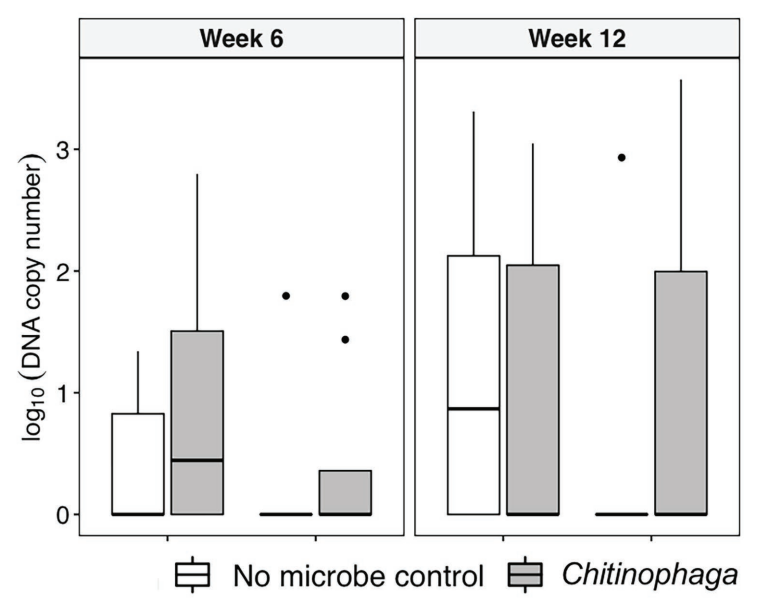

B

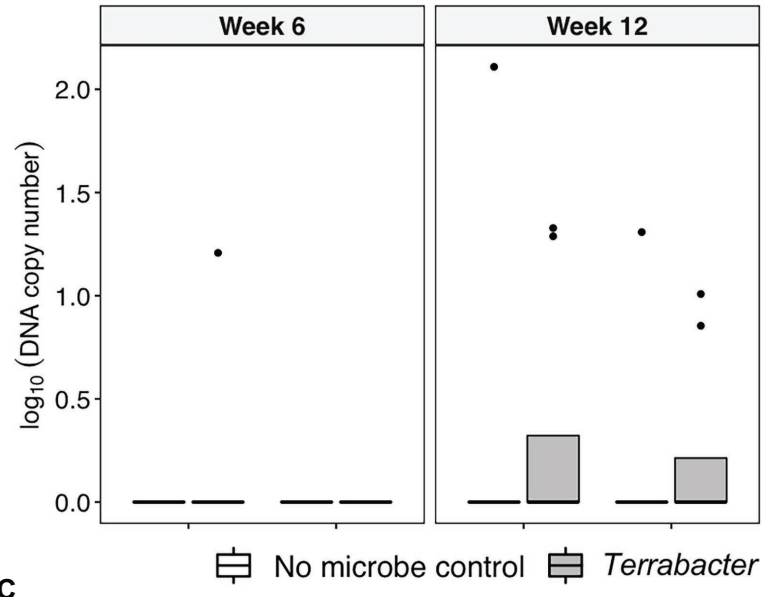

C

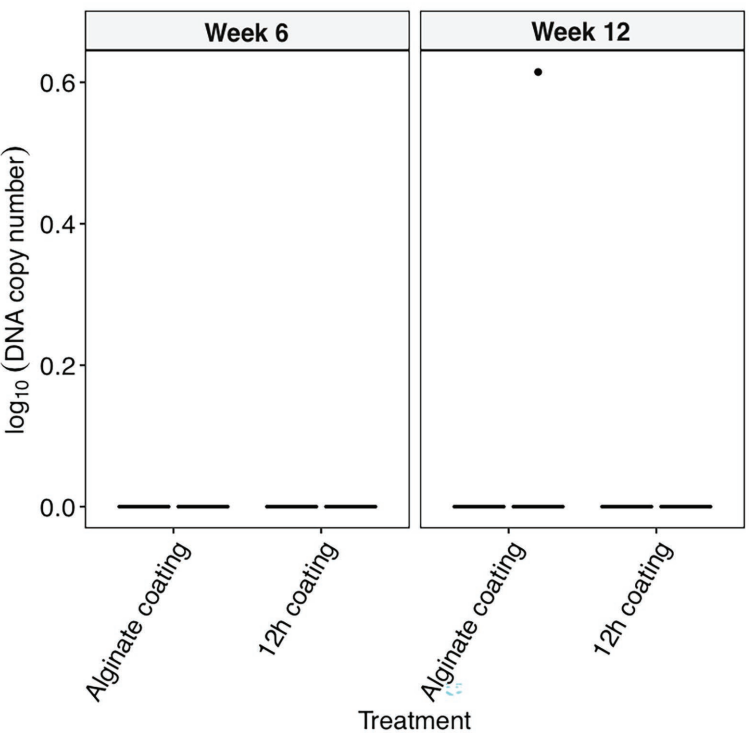

FIGURE 5 | The colonization [ $\log _{10}$ (bacterial DNA copy number)/ng of rhizosphere DNA] of (A) C. rhizosphaerae, (B) C. pinensis, and (C) Terrabacter $\mathrm{sp}$. in the rhizosphere of $\mathrm{S}$. bicolor inoculated with alginate and $12 \mathrm{~h}$ coating at week 6 and 12 after planting under field condition. ANOVA was performed with Tukey's HSD correction for multiple comparisons.
A

追 No microbe control 追 Caulobacter 追 Chitinophaga 追 Terrabacter
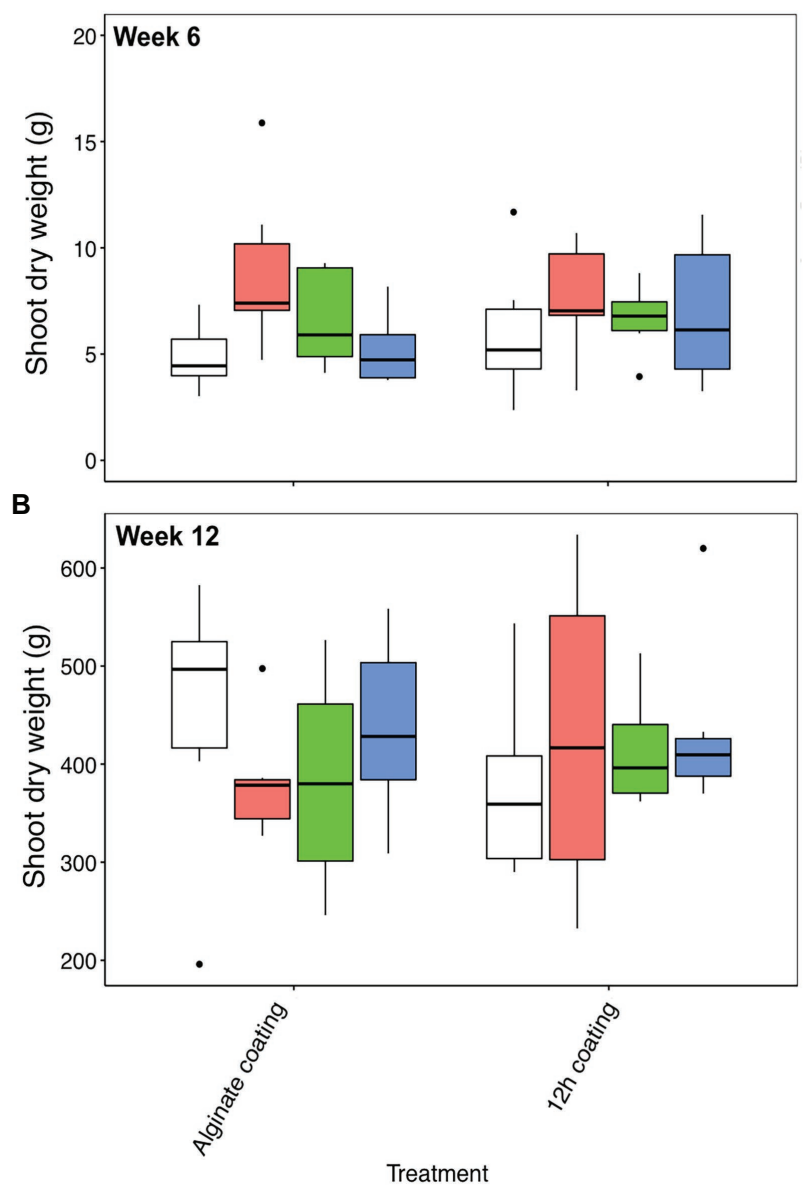

FIGURE 6 | Shoot dry weight of Sorghum bicolor inoculated with each bacterium using alginate and $12 \mathrm{~h}$ coating at (A) week 6 and (B) week 12 after planting in field. ANOVA was performed with Tukey's HSD correction for multiple comparisons. Asterisks denote significant difference in the shoot dry weight between inoculated plants and uninoculated controls.

background colonization levels or any growth promotion, our findings highlight the importance of testing inoculation methods under various conditions to ensure their efficacy under varying environments.

The results from the greenhouse study showed that all the bacterial inoculants used were able to persist in the sorghum rhizosphere or root until the end of the 8-week experiment. The persistence of bioinoculants over a targeted functional period is important so that their downstream impacts on plants could be sustained without needing to add another inoculant booster (Kaminsky et al., 2019). Although C. rhizosphaerae and C. pinensis were detected in the uninoculated plants on week 8 , they were not observed in the controls from week 4 to week 6 . We postulate that the detection of these two bacteria in the uninoculated plants may be attributed to cross-contamination between the uninoculated and inoculated samples collected at week 8 . This may also be due to the amplification of closely related strains that survived the 
soil sterilization and colonized sorghum later in the experiment since the genera Caulobacter and Chitinophaga are ubiquitous in soil (Fulthorpe et al., 2008; Wilhelm, 2018). Although we confirmed the specificity of each primer pairs by blasting the bacterial gene fragments used to design each primer pair against the NCBI database and also ensured that they do not amplify the similar isolates in our cultural collection that were in the same genera as the targeted bacteria, there may be more closely related strains that have not been discovered and sequenced. Our findings further demonstrated that two out of the three bacteria tested were effective in promoting sorghum root and shoot growth. To gain insight into why plant biomass was enhanced, we looked more closely at the bacterial genomic sequences which suggested genes underlying plant growth-promoting functions. For example, $C$. pinensis possesses 1-aminocyclopropane-1-carboxylate deaminase gene which is important for ameliorating plant stress (Glick, 2014) while $C$. pinensis and C. rhizosphaerae have genes encoding siderophore synthetase and transport system that may be important in solubilizing iron in soil (Kramer et al., 2020). A follow-up in vivo survey will be needed to confirm the mechanisms underpinning the plant growth-promoting properties of the bacteria used in this study.

\section{Caulobacter rhizosphaerae and Terrabacter sp. Colonized the Rhizosphere While Chitinophaga pinensis Established in Both Rhizosphere and Root Endosphere}

In this study, the compartmental specificity of the three inoculated bacterial isolates was demonstrated, with $C$. pinensis being the only strain that robustly colonized both the rhizosphere and root endosphere, whereas the other two were only able to colonize the rhizosphere. This result was in agreement with our expectations and other studies (Bai et al., 2015; Maggini et al., 2019) that show inoculated bacteria tend to colonize the plant compartments from which they are isolated. The degree of plant growth-promotion from C. pinensis was not greater than the other two bacterial isolates, although endophytic colonization could theoretically allow bacteria to interact directly with the host plant and potentially deliver the plant growthpromoting effects more efficient than the bacteria in the rhizosphere (Santoyo et al., 2016). Nonetheless, the compartmental specificity of inoculants may be crucial in determining their downstream impact on plants. For example, root nodule colonization of rhizobia is crucial for enhancing the nitrogen nutrition in the host plant because the root nodule restricts the entry of oxygen that can inhibit biological nitrogen fixation (Lindström and Mousavi, 2020).

\section{Generalizations About Inoculation Methods for Bacteria}

Seed inoculation is currently the most widely used approach for the introduction of bioinoculants because it is the most practical and cost-effective compared to other approaches (e.g., in-furrow inoculation; O'Callaghan, 2016). Nevertheless, we found that seed coating methods may not be suitable for the inoculation of Gram-negative bacteria, which may be due to their thinner cell wall structure that renders them vulnerable to desiccation in the seed coating process (Schimel et al., 2007). In accordance with our hypothesis, the seed coating methods were less effective in delivering the Gramnegative bacteria ( $C$. rhizosphaerae and $C$. pinensis) to the sorghum rhizosphere compared to seedling priming and soil drench whereas the Gram-positive strain (Terrabacter sp.) could be delivered successfully with seed coating. Interestingly, we also observed increased colonization from $C$. pinensis but not $C$. rhizosphaerae with the $12 \mathrm{~h}$ seed coating method. Since $C$. pinensis is a root endophyte, we speculate that it may have colonized the seed endophytically during the longer seed coating process (Kandel et al., 2017), thereby enhancing its survival under desiccation. Similar results were also demonstrated in another study in which $12 \mathrm{~h}$ seed coating promoted the initial rhizosphere colonization of an endophytic biocontrol bacterium, Serratia plymuthica HRO-C48, on oilseed rape and enhanced the survival of this bacterium on seeds (Müller and Berg, 2007). Different inoculation methods may further affect the downstream impacts of inoculants on plants. For instance, seed inoculation of Gram-positive Bacillus strains on cowpea and mash bean has been shown to suppress root-infecting phytopathogens more effectively than soil drench (Dawar et al., 2010). The improved biocontrol abilities from these inoculants with seed inoculation may be attributed to the fact that seed inoculation allowed them to establish inside the root prior to pathogen infestation. On the other hand, soil drench has been shown to be more effective in delivering inoculants to Italian ryegrass growing on soil contaminated with diesel oil than the $12 \mathrm{~h}$ seed coating method, and improved plant growth-promotion and hydrocarbon degradation (Afzal et al., 2012). This was probably due to the greater density of inoculant being applied from the soil drench than the $12 \mathrm{~h}$ coating method in which the amount of bacteria applied to seeds was constrained by the seed size. These findings suggest that it may be important to tailor inoculation methods for inoculants with specific characteristics and functionalities.

\section{Colonization Rates Are Not Linked to Growth Promotion}

Although all the inoculation methods tested successfully delivered bacterial isolates to the sorghum rhizosphere in the greenhouse study, the impacts on sorghum growth were variable. Despite being equally effective at delivering $C$. pinensis to sorghum rhizosphere, no growth-promotion was observed with the soil drench method while both shoot and root growth promotions were detected with seedling priming. Similarly, Burkholderia ambifaria MCI 7 was reported to improve maize growth when coated on seed but was detrimental to growth when applied into the soil (Ciccillo et al., 2002). Although it was unclear why the same bacterium had contrasting effects on plant growth, the authors noted that the root adjacent to the stem was mainly colonized when the seed was coated whereas the entire root system was colonized with the soil drench method (Ciccillo et al., 2002). In our studies, Terrabacter sp. was in lower abundance in the rhizosphere but was still able to promote sorghum root 
growth comparable to or better than the other two bacteria. This is in line with another study that observed similar biomasspromoting effects on banana from Pseudomonas fluorescens Ps006 and Bacillus amyloliquefaciens Bs006 despite P. fluorescens Ps006 being a less efficient root colonizer compared to B. amyloliquefaciens Bs006 (Gamez et al., 2019). These findings highlight that the degree of colonization by inoculated bacteria of host plants may not necessarily be directly related to the level of growth enhancement induced.

\section{CONCLUSION}

This study compared several different bacterial inoculation methods to determine the most suitable approach for studies of the impact of bacterial inoculation of plants grown in sterilized greenhouse soil experiments and in the field. Simply coating seeds with a bacterial suspension was suitable for the inoculation and successful colonization of Gram-positive bacteria in the greenhouse, whereas the field results were inconclusive. For Gram-negative bacteria direct inoculation using seedling priming or soil drench led to higher colonization efficiency than seed coating. The method of inoculation was critical in these types of experiments because the colonization rates and plant growth-promoting potential of inoculants were influenced by inoculation method. These findings show that the inoculation methods should be tailored to accommodate the characteristics of different bacterial inoculants to ensure successful colonization of the targeted plant species.

\section{DATA AVAILABILITY STATEMENT}

The datasets presented in this study can be found in online repositories. The names of the repository/repositories and

\section{REFERENCES}

Afzal, M., Yousaf, S., Reichenauer, T. G., and Sessitsch, A. (2012). The inoculation method affects colonization and performance of bacterial inoculant strains in the phytoremediation of soil contaminated with diesel oil. Int. J. Phytoremediation 14, 35-47. doi: 10.1080/15226514.2011.552928

Andrews, M., and Andrews, M. E. (2017). Specificity in legume-rhizobia symbioses. Int. J. Mol. Sci. 18:705. doi: 10.3390/ijms18040705

Bai, Y., Muller, D. B., Srinivas, G., Garrido-Oter, R., Potthoff, E., Rott, M., et al. (2015). Functional overlap of the Arabidopsis leaf and root microbiota. Nature 528, 364-369. doi: 10.1038/nature16192

Bhattacharyya, D., Duta, S., Yu, S.-M., Jeong, S. C., and Lee, Y. H. (2018). Taxonomic and functional changes of bacterial communities in the rhizosphere of kimchi cabbage after seed bacterization with Proteus vulgaris JBLS202. Plant Pathol. J. 34, 286-296. doi: 10.5423/PPJ.OA.03.2018.0047

Boyles, R. E., Brenton, Z. W., and Kresovich, S. (2019). Genetic and genomic resources of sorghum to connect genotype with phenotype in contrasting environments. Plant J. 97, 19-39. doi: 10.1111/tpj.14113

Campo, R. J., Araujo, R. S., Luís, F. M., and Hungria, M. (2010). In-furrow inoculation of soybean as alternative to fungicide and micronutrient seed treatment. R. Bras. Ci. Solo 34, 1103-1112. doi: 10.1590/S0100-06832010000400010

Carlstrom, C. I., Field, C. M., Bortfeld-Miller, M., Muller, B., Sunagawa, S., and Vorholt, J. A. (2019). Synthetic microbiota reveal priority effects and keystone strains in the Arabidopsis phyllosphere. Nat. Ecol. Evol. 3, 1445-1454. doi: 10.1038/s41559-019-0994-z accession number(s) can be found in the article/ supplementary material.

\section{AUTHOR CONTRIBUTIONS}

DS contributed in conceptualization of experiment and revisions of the manuscript. YNC performed the experiment and statistical analyses and wrote the manuscript. SF helped with planting and maintaining the field, as well as sampling. All authors contributed to the article and approved the submitted version.

\section{FUNDING}

This research was funded by United States Department of Energy BER, Grant/Award Number: DE-SC0014395 and the University of Nebraska - Lincoln Agricultural Research Division.

\section{ACKNOWLEDGMENTS}

We thank Drew Tyre for the advice on the statistical analyses. This research was supported by the Office of Science (BER), U.S. Department of Energy (DE-SC0014395) and the University of Nebraska - Lincoln Agricultural Research Division.

\section{SUPPLEMENTARY MATERIAL}

The Supplementary Material for this article can be found online at: https://www.frontiersin.org/articles/10.3389/fmicb.2022. 791110/full\#supplementary-material

Chai, Y. N., Ge, Y., Stoerger, V., and Schachtman, D. P. (2021). High-resolution phenotyping of sorghum genotypic and phenotypic responses to low nitrogen and synthetic microbial communities. Plant Cell Environ. 44, 1611-1626. doi: $10.1111 /$ pce. 14004

Chiniquy, D., Barnes, E. M., Zhou, J., Hartman, K., Li, X., Sheflin, A., et al. (2021). Microbial community field surveys reveal abundant pseudomonas population in sorghum rhizosphere composed of many closely related phylotypes. Front. Microbiol. 12:598180. doi: 10.3389/fmicb.2021.598180

Chung, E. J., Park, T. S., Jeon, C. O., and Chung, Y. R. (2012). Chitinophaga oryziterrae sp. nov., isolated from the rhizosphere soil of rice (Oryza sativa L.). Int. J. Syst. Evol. Microbiol. 62, 3030-3035. doi: 10.1099/ijs.0.036442-0

Ciccillo, F., Fiore, A., Bevivino, A., Dalmastri, C., Tabacchioni, S., and Chiarini, L. (2002). Effects of two different application methods of Burkholderia ambifaria MCI 7 on plant growth and rhizospheric bacterial diversity. Environ. Microbiol. 4, 238-245. doi: 10.1046/j.1462-2920.2002.00291.x

Costanzo, M. C., Crawford, M. E., Hirschman, J. E., Kranz, J. E., Olsen, P., Robertson, L. S., et al. (2001). YPD, PombePD and WormPD: model organism volumes of the BioKnowledge library, an integrated resource for protein information. Nucleic Acids Res. 29, 75-79. doi: 10.1093/nar/29.1.75

Dawar, S., Wahab, S., Tariq, M., and Zaki, M. J. (2010). Application of Bacillus species in the control of root rot diseases of crop plants. Arch. Phytopathol. Plant Protect. 43, 412-418. doi: 10.1080/03235400701850870

Delaux, P.-M., and Schornack, S. (2021). Plant evolution driven by interactions with symbiotic and pathogenic microbes. Science 371:eaba6605. doi: 10.1126/ science.aba6605 
Dohrmann, A. B., Küting, M., Jünemann, S., Jaenicke, S., Schlüter, A., and Tebbe, C. C. (2013). Importance of rare taxa for bacterial diversity in the rhizosphere of Bt- and conventional maize varieties. ISME J. 7, 37-49. doi: 10.1038/ismej.2012.77 Egamberdieva, D., Wirth, S. J., Alqarawi, A. A., Abd_Allah, E. F., and Hashem, A. (2017). Phytohormones and beneficial microbes: essential components for plants to balance stress and fitness. Front. Microbiol. 8:2104. doi: 10.3389/ fmicb.2017.02104

Fukami, J., Nogueira, M. A., Araujo, R. S., and Hungria, M. (2016). Accessing inoculation methods of maize and wheat with Azospirillum brasilense. AMB Express 6:3. doi: 10.1186/s13568-015-0171-y

Fulthorpe, R. R., Roesch, L. F. W., Riva, A., and Triplett, E. W. (2008). Distantly sampled soils carry few species in common. ISME J. 2, 901-910. doi: 10.1038/ ismej.2008.55

Gamez, R., Cardinale, M., Montes, M., Ramirez, S., Schnell, S., and Rodriguez, F. (2019). Screening, plant growth promotion and root colonization pattern of two rhizobacteria (Pseudomonas fluorescens Ps006 and Bacillus amyloliquefaciens Bs006) on banana cv. Williams (Musa acuminata Colla). Microbiol. Res. 220, 12-20. doi: 10.1016/j.micres.2018.11.006

Gao, J. L., Sun, P., Sun, X. H., Tong, S., Yan, H., Han, M. L., et al. (2018). Caulobacter zeae sp. nov. and Caulobacter radicis sp. nov., novel endophytic bacteria isolated from maize root (Zea mays L.). Syst. Appl. Microbiol. 41, 604-610. doi: 10.1016/j.syapm.2018.08.010

García-Fraile, P., Carro, L., Robledo, M., Ramírez-Bahena, M.-H., Flores-Félix, J.-D., Fernández, M. T., et al. (2012). Rhizobium promotes non-legumes growth and quality in several production steps: towards a biofertilization of edible raw vegetables healthy for humans. PLoS One 7:e38122. doi: 10.1371/journal.pone.0038122

Glick, B. R. (2014). Bacteria with ACC deaminase can promote plant growth and help to feed the world. Microbiol. Res. 169, 30-39. doi: 10.1016/j. micres.2013.09.009

Harman, G. E., and Uphoff, N. (2019). Symbiotic root-endophytic soil microbes improve crop productivity and provide environmental benefits. Scientifica 2019:9106395. doi: 10.1155/2019/9106395

Hoagland, D. R., and Arnon, D. I. (1950). The water-culture method for growing plants without soil. Calif. Agric. Exp. Stn. Circ. 347, 1-32.

Hottes, A. K., Meewan, M., Yang, D., Arana, N., Romero, P., Mcadams, H. H., et al. (2004). Transcriptional profiling of Caulobacter crescentus during growth on complex and minimal media. J. Bacteriol. 186, 1448-1461. doi: 10.1128/ JB.186.5.1448-1461.2004

Hungria, M., Nogueira, M. A., and Araujo, R. S. (2013). Co-inoculation of soybeans and common beans with rhizobia and azospirilla: strategies to improve sustainability. Biol. Fertil. Soils 49, 791-801. doi: 10.1007/s00374-012-0771-5

Kaminsky, L. M., Trexler, R. V., Malik, R. J., Hockett, K. L., and Bell, T. H. (2019). The inherent conflicts in developing soil microbial inoculants. Trends Biotechnol. 37, 140-151. doi: 10.1016/j.tibtech.2018.11.011

Kandel, S. L., Joubert, P. M., and Doty, S. L. (2017). Bacterial endophyte colonization and distribution within plants. Microorganisms 5:77. doi: 10.3390/ microorganisms5040077

Kassambara, A. (2020). ggpubr: 'ggplot2' Based publication ready plots. R package version 0.4.0. Available at: https:/CRAN.R-project.org/package=ggpubr (Accessed November 1, 2021).

Kramer, J., Özkaya, Ö., and Kümmerli, R. (2020). Bacterial siderophores in community and host interactions. Nat. Rev. Microbiol. 18, 152-163. doi: 10.1038/s41579-019-0284-4

Ledermann, R., Schulte, C. C. M., Poole, P. S., and Margolin, W. (2021). How rhizobia adapt to the nodule environment. J. Bacteriol. 203:e0053920. doi: 10.1128/JB.00539-20

Lenth, R. V. (2021). Emmeans: estimated marginal means, aka least-squares means. R package version 1.6.3.

Li, X., Rui, J., Mao, Y., Yannarell, A., and Mackie, R. (2014). Dynamics of the bacterial community structure in the rhizosphere of a maize cultivar. Soil Biol. Biochem. 68, 392-401. doi: 10.1016/j.soilbio.2013.10.017

Lindström, K., and Mousavi, S. A. (2020). Effectiveness of nitrogen fixation in rhizobia. Microb. Biotechnol. 13, 1314-1335. doi: 10.1111/1751-7915.13517

Lobo, C. B., Juárez Tomás, M. S., Viruel, E., Ferrero, M. A., and Lucca, M. E. (2019). Development of low-cost formulations of plant growth-promoting bacteria to be used as inoculants in beneficial agricultural technologies. Microbiol. Res. 219, 12-25. doi: 10.1016/j.micres.2018.10.012

Lopes, L. D., Chai, Y. N., Marsh, E. L., Rajewski, J. F., Dweikat, I., and Schachtman, D. P. (2021a). Sweet sorghum genotypes tolerant and sensitive to nitrogen stress select distinct root endosphere and rhizosphere bacterial communities. Microorganisms 9:1329. doi: 10.3390/microorganisms 9061329

Lopes, M. J. D. S., Dias-Filho, M. B., and Gurgel, E. S. C. (2021b). Successful plant growth-promoting microbes: inoculation methods and abiotic factors. Front. Sustain. Food Syst. 5:606454. doi: 10.3389/fsufs.2021.606454

Luna, M. F., Galar, M. L., Aprea, J., Molinari, M. L., and Boiardi, J. L. (2010). Colonization of sorghum and wheat by seed inoculation with Gluconacetobacter diazotrophicus. Biotechnol. Lett. 32, 1071-1076. doi: 10.1007/s10529-010-0256-2

Lupwayi, N. Z., Olsen, P. E., Sande, E. S., Keyser, H. H., Collins, M. M., Singleton, P. W., et al. (2000). Inoculant quality and its evaluation. Field Crop Res. 65, 259-270. doi: 10.1016/S0378-4290(99)00091-X

Maggini, V., Mengoni, A., Gallo, E. R., Biffi, S., Fani, R., Firenzuoli, F., et al. (2019). Tissue specificity and differential effects on in vitro plant growth of single bacterial endophytes isolated from the roots, leaves and rhizospheric soil of Echinacea purpurea. BMC Plant Biol. 19:284. doi: 10.1186/s12870-019-1890-Z

McPherson, M. R., Wang, P., Marsh, E. L., Mitchell, R. B., and Schachtman, D. P. (2018). Isolation and Analysis of Microbial Communities in Soil, Rhizosphere, and Roots in Perennial Grass Experiments. J. Vis. Exp. 137:57932. doi: 10.3791/57932

Mendes, R., Garbeva, P., and Raaijmakers, J. M. (2013). The rhizosphere microbiome: significance of plant beneficial, plant pathogenic, and human pathogenic microorganisms. FEMS Microbiol. Rev. 37, 634-663. doi: 10.1111/1574-6976.12028

Mendoza-Suárez, M., Andersen, S. U., Poole, P. S., and Sánchez-Cañizares, C. (2021). Competition, nodule occupancy, and persistence of inoculant strains: key factors in the rhizobium-legume symbioses. Front. Plant Sci. 12:690567. doi: $10.3389 /$ fpls.2021.690567

Müller, H., and Berg, G. (2007). Impact of formulation procedures on the effect of the biocontrol agent Serratia plymuthica HRO-C48 on Verticillium wilt in oilseed rape. BioControl 53, 905-916. doi: 10.1007/s10526-007-9111-3

O'callaghan, M. (2016). Microbial inoculation of seed for improved crop performance: issues and opportunities. Appl. Microbiol. Biotechnol. 100, 5729-5746. doi: 10.1007/s00253-016-7590-9

Parniske, M. (2008). Arbuscular mycorrhiza: the mother of plant root endosymbioses. Nat. Rev. Microbiol. 6, 763-775. doi: 10.1038/nrmicro1987

Price, M. N., Dehal, P. S., and Arkin, A. P. (2010). FastTree 2-approximately maximum-likelihood trees for large alignments. PLoS One 5:e9490. doi: 10.1371/journal.pone.0009490

R Developmental Core Team (2018). R: A Language and Environment for Statistical Computing. R Foundation for Statistical Computing.

Reasoner, D. J., and Geldreich, E. E. (1985). A new medium for the enumeration and subculture of bacteria from potable water. Appl. Environ. Microbiol. 49, 1-7. doi: 10.1128/aem.49.1.1-7.1985

Rocha, I., Ma, Y., Souza-Alonso, P., Vosatka, M., Freitas, H., and Oliveira, R. S. (2019). Seed coating: a tool for delivering beneficial microbes to agricultural crops. Front. Plant Sci. 10:1357. doi: 10.3389/fpls.2019.01357

Santi, C., Bogusz, D., and Franche, C. (2013). Biological nitrogen fixation in non-legume plants. Ann. Bot. 111, 743-767. doi: 10.1093/aob/mct048

Santos, M. S., Nogueira, M. A., and Hungria, M. (2019). Microbial inoculants: reviewing the past, discussing the present and previewing an outstanding future for the use of beneficial bacteria in agriculture. AMB Express 9:205. doi: 10.1186/s13568-019-0932-0

Santoyo, G., Moreno-Hagelsieb, G., Del Carmen Orozco-Mosqueda, M., and Glick, B. R. (2016). Plant growth-promoting bacterial endophytes. Microbiol. Res. 183, 92-99. doi: 10.1016/j.micres.2015.11.008

Schimel, J., Balser, T. C., and Wallenstein, M. (2007). Microbial stress-response physiology and its implications for ecosystem function. Ecology 88, 1386-1394. doi: $10.1890 / 06-0219$

Tonitto, C., and Ricker-Gilbert, J. E. (2016). Nutrient management in African sorghum cropping systems: applying meta-analysis to assess yield and profitability. Agron. Sustain. Dev. 36:10. doi: 10.1007/s13593-015-0336-8

Vassilev, N., Vassileva, M., Martos, V., Garcia Del Moral, L. F., Kowalska, J., Tylkowski, B., et al. (2020). Formulation of microbial inoculants by encapsulation in natural polysaccharides: focus on beneficial properties of carrier additives and derivatives. Front. Plant Sci. 11:270. doi: 10.3389/fpls.2020.00270

Venables, W. N., and Ripley, B. D. (2002). Modern Applied Statistics with S. 4th Edn. New York: Springer.

Viaene, T., Langendries, S., Beirinckx, S., Maes, M., and Goormachtig, S. (2016). Streptomyces as a plant's best friend? FEMS Microbiol. Ecol. 92:fiw119. doi: 10.1093/femsec/fiw119 
Weller, D. M. (2007). Pseudomonas biocontrol agents of soilborne pathogens: looking back over 30 years. Phytopathology 97, 250-256. doi: 10.1094/PHYTO-97-2-0250

Wickham, H. (2016). ggplot2: Elegant Graphics for Data Analysis. New York: Springer-Verlag.

Wilhelm, R. C. (2018). Following the terrestrial tracks of Caulobacter-redefining the ecology of a reputed aquatic oligotroph. ISME J. 12, 3025-3037. doi: 10.1038/s41396-018-0257-Z

Wippel, K., Tao, K., Niu, Y., Zgadzaj, R., Kiel, N., Guan, R., et al. (2021). Host preference and invasiveness of commensal bacteria in the lotus and Arabidopsis root microbiota. Nat. Microbiol. 6, 1150-1162. doi: 10.1038/s41564-021-00941-9

Xu, L., Naylor, D., Dong, Z., Simmons, T., Pierroz, G., Hixson, K. K., et al. (2018). Drought delays development of the sorghum root microbiome and enriches for monoderm bacteria. Proc. Natl. Acad. Sci. U. S. A. 115, E4284-E4293. doi: $10.1073 /$ pnas. 1717308115

Zaidi, A., Khan, M. S., Ahemad, M., and Oves, M. (2009). Plant growth promotion by phosphate solubilizing bacteria. Acta Microbiol. Immunol. Hung. 56, 263-284. doi: 10.1556/AMicr.56.2009.3.6
Conflict of Interest: The authors declare that the research was conducted in the absence of any commercial or financial relationships that could be construed as a potential conflict of interest.

Publisher's Note: All claims expressed in this article are solely those of the authors and do not necessarily represent those of their affiliated organizations, or those of the publisher, the editors and the reviewers. Any product that may be evaluated in this article, or claim that may be made by its manufacturer, is not guaranteed or endorsed by the publisher.

Copyright (c) 2022 Chai, Futrell and Schachtman. This is an open-access article distributed under the terms of the Creative Commons Attribution License (CC BY). The use, distribution or reproduction in other forums is permitted, provided the original author(s) and the copyright owner(s) are credited and that the original publication in this journal is cited, in accordance with accepted academic practice. No use, distribution or reproduction is permitted which does not comply with these terms. 